УДК 811.111 '(271.2+42)'06:808.51

DOI https://doi.org/10.26661/2414-1135-2021-83-6

\title{
РЕГУЛЯРНА ТА ДИСКУРС-СПЕЦИФІЧНА АНГЛОМОВНА МЕТАКОМУНІКАЦІЯ: ПОСТАНОВКА ПРОБЛЕМИ
}

\author{
Гнезділова Я. В. \\ доктор філологічних наук, дочент, \\ завідувач кафедри фонетики і практики англійської мови \\ Київський національний лінгвістичний університет \\ вул. Велика Васильківська, 73, Київ, Україна \\ orcid.org/0000-0001-9248-3238 \\ yaroslava.gnezdilova@knlu.edu.ua
}

\author{
Ключові слова: \\ метакомунікація, \\ метакомунікатив, мета- \\ індекс, метакомунікативне \\ знання, типи дискурсу.
}

У статті ідентифіковано «регулярну й дискурс-специфічну метакомунікацію», де метакомунікацію представлено як прагмакогнітивний феномен. Зауважено основний критерій типологізації метакомунікації, яким $\epsilon$ спосіб вияву метакомунікативного знання. Установлено, що регулярна метакомунікація $\epsilon$ експліцитним відображенням того, що відбувається в поточній комунікації, і базується на регулярних стереотипних патернах, притаманних усім/майже всім типам дискурсу, «оформлених» згідно зі стандартами інтеракційних жанрів, до яких вони належать. Схарактеризовано автономні метакомунікативи (MК) як регулярні, експліцитні, контекстуально незалежні, високо конвенціалізовані й семантично спустошені, стереотипні одиниці, які класифіковано в шість основних груп: контактно-фатичні, регулятивні, референційні, рефлективні, логіко-композиційні, суб'єктно-модальні МК. Доведено, що до найпоширеніших МК регулярної метакомунікації відносяться контактно-фатичні, регулятивні й рефлективні МК, рідковживаними є суб'єктно-модальні МК. 3'ясовано, що реалізація прагматичних інтенцій мовців відбувається шляхом вибору адекватних для відповідного типу дискурсу (розмов ного, юридичного, медійного, риторичного, науково-академічного) стереотипних клішованих структур, які віднесено до дискурс-специфічних МК. Зазначено, що для аналізу англомовної метакомунікації вибір дискурсів здійснено за мовленнєвожанровою диференціацією на основі того, що мовленнєві жанри, які типологізовано відповідно до традиційних класифікацій функціональних стилів (розмовний, науковий, офіційно-діловий, публіцистичний), нині розглядають у термінах дискурсознавства як дискурсивні сфери мовлення. Уточнено, що дискурс-специфічні МК теж є часто вживаними одиницями, але обмеженими певним дискурсивним типом, тому їх визначено як «регулярні МК відповідного типу дискурсу». Обгрунтовано, що «найметакомунікативнішими» $\epsilon$ усний медійний i риторичний дискурси, а найнижчий мета-індекс - у юридичному дискурсі; найчастотнішими в усіх досліджуваних типах дискурсів, окрім розмовного, є МК-регулятиви, натомість розмовний дискурс вирізняється саме фатичною метакомунікацією. 


\title{
REGULAR AND DISCOURSE-SPECIFIC ENGLISH METACOMMUNICATION: PROBLEM STATEMENT
}

\author{
Gnezdilova Ya. V. \\ Doctor of Philological Sciences, Associate Professor, \\ Head of the Department of Phonetics, Spoken and Written English \\ Kyiv National Linguistic University \\ Velyka Vasylkivska str., 73, Kyiv, Ukraine \\ orcid.org/0000-0001-9248-3238 \\ yaroslava.gnezdilova@knlu.edu.ua
}

Key words: metacommunication, meta-index, meta-means, metapragmatic awareness, discourse types.
The article identifies "regular and discourse-specific metacommunication"; notably, it observes metacommunication as a pragmatic and cognitive phenomenon. It indicates the main criterion used in the metacommunication typology, which is metapragmatic awareness and the ways of its realization. The research establishes that regular metacommunication is an explicit reflection of what is going on in real communication; consequently, it bases on regular stereotypic patterns used in (almost) all discourse types and shaped in accordance with the norms of the speech genres they belong to. It characterizes autonomous meta-means as regular, explicit, contextually independent, highly conventionalized, semantically empty, and stereotypic lexicon, which have been classified into six main groups: phatic, regulative, referential, reflective, cohesive and modal. The article confirms that the most widespread regular meta-means are phatic, regulative, and reflective, while modal ones are the least frequent. It also demonstrates that pragmatic intentions of the speaker realize through the choice of stereotypic clichés, typical for a certain discourse type (everyday, law, media, rhetoric, academic or scientific), and viewed as discourse-specific meta-means. In the context of the discourse-analysis of English metacommunication, the author enlightens that the above-mentioned discourse types have been selected by speech genres criterion, as speech genres, classified according to the traditional functional styles (oral, academic, official, social-political etc.) are, in terms of discourse studies, now equalled to discourse types. The study specifies that discourse-specific meta-means are also frequently used but only within certain discourse type; thus, they have been defined as "regular meta-means of certain discourse type". It proves that "most metacommunicative" are oral media and rhetoric discourses, and the lowest meta-index is in law discourse; in all discourses under analysis, but for everyday one, most frequently used are regulative meta-means, while the everyday discourse has been characterized as phatic.
Постановка проблеми. Сучасна лінгвокомунікативістика й у XXI ст. залишається однією 3 «провідних лінгвістичних теорій», яка, базуючись на принципах антропоцентризму й дискурсоцентризму, продовжує викликати науковий інтерес до неї. Останнім часом лінгвокомунікативістика зосередила увагу передовсім на дослідженні мовленнєвої взаємодії комунікантів, зокрема на тих іiі аспектах, які пов'язані з пошуками лінгвосинергетичних інструментів для досягнення гармонійного й успішного спілкування, ключовим компонентом якого є метакомунікація.

Термін «метакомунікація», ужитий англійським лінгвістом Ірегорі Бейтсоном ще в 1951 році в праці «Communication: The Social
Matrix of Psychiatry», до якого згодом у 1967 році повернулися американські лінгвісти П. Вацлавік, Дж. Бівін і Д. Джексон у роботі «Pragmatics of human communication», широкого резонансу він набув у 80-х - 90-х рр. ХХ ст. після виходу у світ праць Г.Г. Почепцова, В.Д. Дєвкіна, В.В. Дементьєва, Т.Д. Чхетіані та ін. Розроблення проблематики метакомунікації триває й дотепер крізь призму теорії дискурсу [1 тощо], теорії мовленнєвих жанрів [2 тощо], теорії мовленнєвих актів [1; 3 тощо], теорії ввічливості [4 тощо], лінгвокогнітивної теорії простору [5] тощо.

Точаться дискусії також навколо понять «комунікація» i «метакомунікація» [5-7], наприклад, на сторінках збірнику наукових праць 
«Communication and Metacommunication in Human Development», 2004 р. (за редакцією А. Бранко та Я. Валсінера). Окрему увагу приділено розробленню оптимальної класифікації метакомунікативних одиниць у науковій збірці «Investigations into the Meta-communicative Lexicon of English. A Contribution to Historical Pragmatics», 2012 p. (за редакцією У. Буссе й А. Хюблера), як і визначенню таких понять, як «метакомунікативна координація» та «метакомунікативна ситуація»; «метакомунікативні висловлення», «метакомунікативні маркери» й «метакомунікативні мовленнєві акти». Найсучасніші дослідження 3 метакомунікації представлені трьома основними напрямами: 1) напрямом ігрової стилістики [8]; 2) напрямом сугестивної лінгвістики й мовленнєвого маніпулювання [9]; 3) напрямом лінгвістичного моделювання, одним і результатів якого є когнітивно-дискурсивна модель метакомунікації [9].

Широковекторність вивчення метакомунікації зумовлена різним трактуванням префікса «мета-», що є формантом на позначення: галузей науки: металінгвістики/метафілології, метаструктуралізму, метапоетики, метапрагматики; рівнів $i$ напрямів лінгвістики: метасеміозису, метасемії, металексикографії, метафонетики; категорій: метадискурсивності, метатекстуальності, метакогнітивності, метамодальності; одинищь дослідження: метамови, метатексту, метажанру, метадискурсу тощо.

У процесі обговорення наукового об'єму поняття «мета комунікація» під час захисту докторської дисертації все ще не вирішеними й нагальними, з огляду на уточнення й рекомендації шановних учених (О.Р. Валігура, А.П. Мартинюк, О.І. Морозова), залишаються питання, що стосуються типології метакомунікації, включаючи широко досліджуваний фатичний ї̈ різновид [1; 3; 6 тощо], статусу метакомунікативів, їх дискурс-специфічних ознак. Окреслений дослідницький вектор викликав необхідність глибшого вивчення дискурсивної зумовленості метакомунікації, зокрема урахування іiї прагматичних характеристик у сучасних англомовних розмовному, юридичному, медійному, риторичному, науково-академічному дискурсах, що й засвідчує актуальність теми статті.

Гіпотеза дослідження полягає в тому, що типологія метакомунікації як прагмакогнітивного феномена взагалі й регулятора мовленнєвої взаємодії зокрема $\epsilon$ наслідком відображення прагматичних інтенцій мовців шляхом вибору адекватних для відповідного типу дискурсу (розмовного, юридичного, медійного, риторичного, науково-академічного) стереотипних клішованих структур. Припускаємо, що кожен тип метакомунікації представлений регулярними стереотипними патернами, притаманними всім/майже всім типам дискурсу, «оформленими» згідно зі стандартами відповідних інтеракційних жанрів, до яких вони належать; водночас кожен дискурсивний тип вирізняється властивими лише йому одиницями, так званими дискурс-специфічними метакомунікативами.

Мета дослідження полягає в типологізації метакомунікації з огляду на частотність уживання метакомунікативів і передбачає вирішення таких завдань: схарактеризувати регулярну метакомунікацію та диференціювати дискурс-специфічну метакомунікацію.

Об'єктом дослідження є англомовна метакомунікація як прагмакогнітивний феномен.

Предмет дослідження становлять критерії диференціації регулярних (автономних) i дискурс-специфічних МК.

Виклад основного матеріалу дослідження. В основу класифікації метакомунікативів зокрема й типологізації метакомунікації загалом покладено вслід за А. Хюблером та У. Буссе [10, p. 2-3] «метакомунікативне знання» [9, с. 59-63, 140-141] та способи його вияву. 3 огляду на поставлені завдання, фокусом статті $є$ перший спосіб вияву метакомунікативного знання, а саме: «експліцитне відображення того, що відбувається в поточній комунікації», що маркує експліцитну метакомунікацію, яка водночас $є$ контекстуально незалежною, адже експліцитні МК досить легко вичленовуються в мовленні й інтерпретуються без глибокого аналізу контексту. Такі МК $є$ високо конвенціалізованими й контекстуально-незалежними чи, іншими словами, автономними одиницями.

Автономні МК є універсальними, адже вони представлені одиницями, побудованими за певною схемою (структурою-основою), часто повторюваними й уживаними в усіх/більшості типів дискурсів. Тобто експлічичтні, автономні $M K \epsilon$ регулярними одиницями мовлення, відповідно, маркують регулярну метакомунікацію. До регулярного автономного лексикону в метакомунікації відносимо парентетичні одиниці, які виконують виключно метакомунікативну функцію, як-от: frankly speaking, I'm fed up, in other words, by the way, of course, in fact тощо; вигуки типу oh, well, hey, які також включають прокльони типу damn you, dammit чи божіння типу my God, for God's sake, Oh my God, Dear God. Ця група МК не обмежується лише вищезазначеними одиницями. Більше того, вона численна [9, с. 140-243], адже включає ті одиниці, які не лімітуються певним дискурсивним типом, а за невеликої варіативності зустрічаються в кількох дискурсах, наприклад, майже в усіх усних чи письмових. Автономні МК легко ідентифікуються, оскільки «варіативності» 
виникають на основі широковживаних стереотипних структур-кліше, видозмінюючи останні. Так, візьмемо регулярний МК you know як такий, що є типовим для усного мовлення взагалі, при цьому до його варіантів належать: you guys know by now; and you know how I feel about; as you know; you know who you are; be it known to you; you know what?, оскільки ці вислови об'єднуються спільним предикатом (you know) і легко вичленовуються в мовленні. Прослідковується також регулярна структура-кліше й у таких парентетичних МК оцінки, як that's good to know; that's perfectly alright; that's nice тощо.

Автономні МК - за критеріями семантичної спустошеності, стереотипності, надмірності, автоматичності, регулятивності, контекстуальної (не)залежності - класифіковано в шість основних груп. Зазначимо, що загальна кількість виявлених регулярних автономних метакомунікативів становить 3433 одиниці, 3-поміж яких: контактнофатичних - 690 од.; МК-регулятивів - 1558 од.; референційних МК - 131 од.; рефлективних МК 584 од.; логіко-композиційних МК - 347 од.; суб'єктно-модальних МК - 123 од. (див. рис. 1).

Різновидом регулярної метакомунікації є дискурс-специфічна метакомунікація на основі того, що кожен тип дискурсу характеризується притаманними саме йому часто вживаними МК, які, власне, є «регулярними МК відповідного типу дискурсу» або, іншими словами, дискурс-специфічними МК. Позаяк дискурс-специфічна метакомунікація передбачає встановлення iii особливостей чи, іншими словами, оптимальне відображення характеристик метакомунікативів i ïх комбінацій у різних типах дискурсу, вибір останніх потребує додаткового обгрунтування.

Зазначимо, що нині в різних науках і лінгвістиці зокрема розроблено власні підходи до типологізації дискурсів. Проте в наукових працях I.С. Шевченко, О.І. Морозової, Н.К. Кравченко, І.Р. Корольова, О.О. Черхави, В.І. Карасика, як правило, виділяють такі критерії для ідентифікації певних типів дискурсу: за формою, за видом мовлення, за адресатною спрямованістю, за комунікативними принципами, за соціально-ситуативним параметром, за каналами інформації, за функціонально-стилістичним аспектом відповідності жанрам i регістрам мовлення. Для аналізу англомовної метакомунікації вибір типу дискурсу відбувався на основі останнього критерію, тобто мовленнєво-жанрової диференціації. За цим критерієм виділяють різні типи дискурсів, 3-поміж яких відібрано сім, окрім художнього типу. Питання класифікації мовленнєвих жанрів дискурсу залишається й досі відкритим. Свого часу М.М. Бахтін виокремив близько 30 мовленнєвих жанрів на основі певних комунікативних ситуацій. Мовленнєві жанри (за Ф.С. Бацевичем), що є об'єктом вивчення в генології, типологізовано відповідно до традиційних класифікацій функціональних стилів (розмовний, науковий, офіційно-діловий, публіцистичний), які останнім часом розглядають у термінах дискурсознавства як дискурсивні сфери мовлення. Так, науковий представлений власне науковим та академічним; офіційно-діловий - юридичним; публіцистичний/публічний риторичним і медійними (радіо/теледискурсом, газетним дискурсом тощо); розмовний - побутовим, корпоративним дискурсами тощо.

Увесь реєстр семи типів дискурсу становлять сценарії 7 повнометражних фільмів і 6 серій серіалів; 13 публічних виступів; 10 наукових статей 3 метапрагматики; транскрипти 5 семінарських $\mathrm{i}$ лекційних занять, тривалістю 83-125 хв. кожне; транскрипти 5 радіо-/телепрограм каналів $C N N$ i $B B C$; 11 статей із друкованих 3MI: The Times, The Telegraph i The New York Times i протоколи 7 судових засідань: Appellate Committee, the County Court, The High Court of Justice, the Magistrates' Court.

Базуючись на аналізові вказаних дискурсів, доведено, що деякі дискурсивні типи $\epsilon$

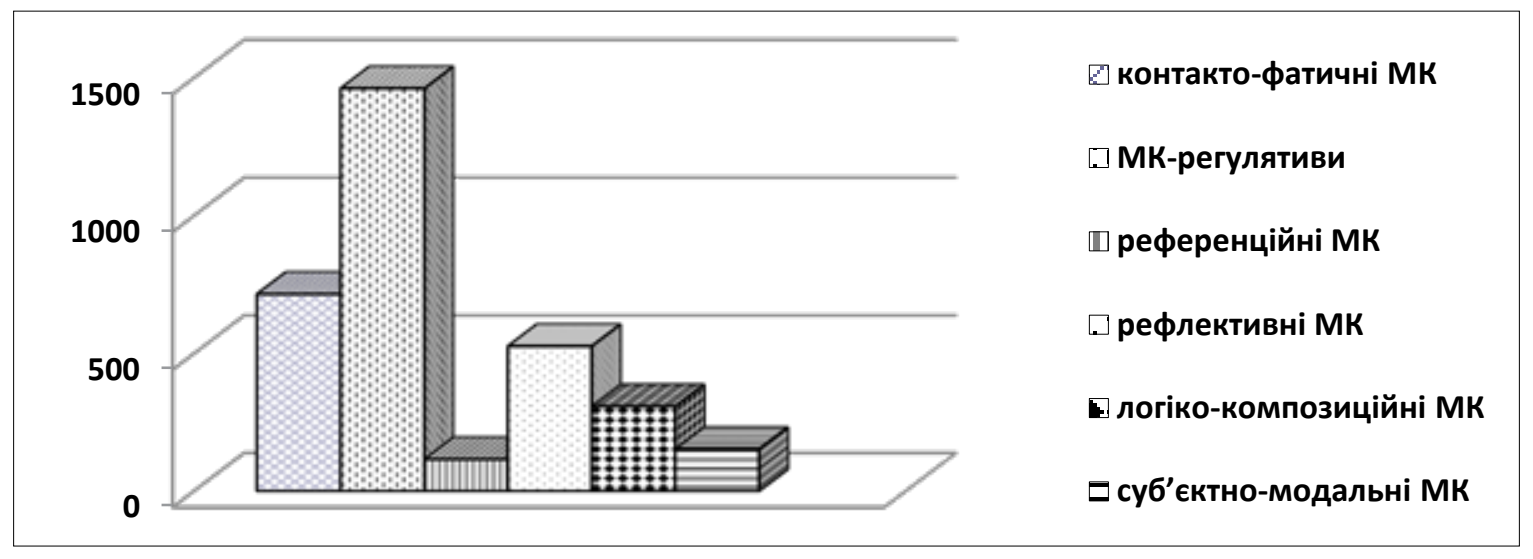

Рис. 1. Співвідношення МК за частотністю їх уживання 


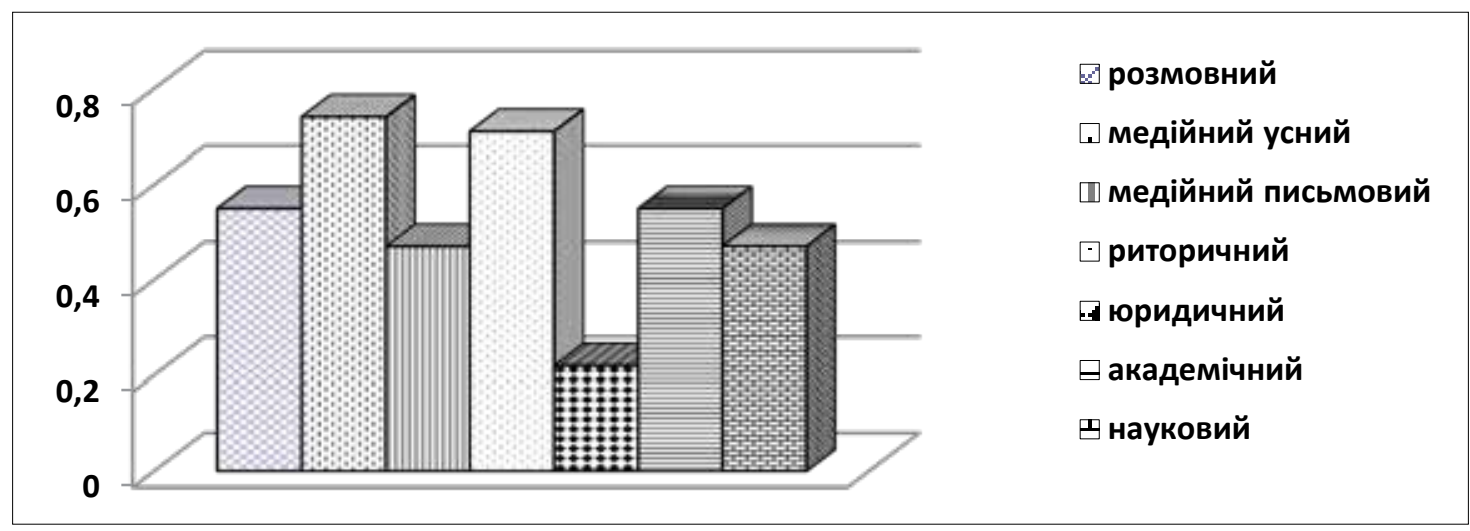

Рис. 2. Співвідношення дискурсів за мета-індексом

«метакомунікативнішими» за інші (див. рис. 2). Найвищий мета-індекс [9, p. 111-118] виявився в медійному усному та риторичному дискурсах (хоча за кількістю МК більше їх у риторичному дискурсі (949 МК) порівняно з усним медійним (594 МК)), високим є мета-індекс у розмовному й академічному дискурсах, а найнижчий мета-індекс - у юридичному дискурсі.

Більше того, кожен тип дискурсу характеризується притаманними саме йому метакомунікативами, адже в разі регулярного використання метакомунікативних висловлень виникають стереотипні патерни як складники того інтеракційного жанру, до якого вони належать. Так, прикладами так-званих «регулярних $M К$ відповідного muny дискурсу» чи дискурс-специфічних МК одиниці типу hi, what's up? You doing ok? You got me there у розмовному дискурсі або Do you swear that this is a true and accurate statement? / Do you swear to well and truly interpret these proceedings, so help you God? у юридичному дискурсі.

Якщо узагальнити, то найчастотнішими в усіх досліджуваних типів дискурсів, окрім розмовного, є МК-регулятиви (45\% у риторичному, $40 \%$ в усному медійному, $48 \%$ у медійному письмовому, $46 \%$ в академічному, $54 \%$ в науковому, $46 \%$ у юридичному дискурсах). У риторичному дискурсі однакова частка належить фатичній і рефлективній метакомунікації (по 20\%); а в усному медійному дискурсі фактично збігаються фатична $(36 \%)$ і регулятивна метакомунікація (40\%). Академічному дискурсу, як і медійному письмовому, характерна рефлективна метакомунікація (29\% i $20 \%$ відповідно), а науковому, як і юридичному, логіко-композиційна (22\% і $15 \%$ відповідно). Розмовний дискурс вирізняється саме фатичною метакомунікацією (49\%).

Висновки й перспективи подальших розробок у цьому напрямі. Метакомунікація як прагмакогнітивний феномен пов'язується з метакомунікативним знанням, що реалізується в мовленні через індикатори чи сигнали для інтерпретації контактно-фатичні, регулятивні, референційні, рефлективні, логіко-композиційні, суб'єктно-модальні МК. За способом вияву метакомунікативного знання виокремлюємо регулярну метакомунікацію, яка водночас $\epsilon$ експліцитною й незалежною. Регулярна метакомунікація включає дискурс-специфічну метакомунікацію як таку, що базується на регулярному використанні метакомунікативів як стереотипних патернів, що $\epsilon$ складниками відповідного типу дискурсу. До найближчих перспектив дослідження відносимо детальне вивчення специфіки реалізації метакомунікації в зазначених типах дискурсу окремо (у розмовному, риторичному, усному й письмовому медійному, академічному, науковому та юридичному дискурсах).

\section{ЛІТЕРАТУРА}

1. Шевченко И.С. (2015). Соотношение информативной и фатической функции как проблема эколингвистики. Когниция, коммуникаиия, дискурс. 2015. № 10. С. 114-132.

2. Дементье В.В. Теория речевых жанров. Москва : Знак, 2010.

3. Почепцов Г.Г. Избранные труды по лингвистике. Харьков : Харьковский национальный университет имени В.Н. Каразина, 2009.

4. Brown P., Levinson S.C. Politeness: Some universals in language usage. Cambridge : Cambridge University Press, 1987.

5. Гуревич Л.С. Лингво-когнитивная теория пространства метакоммуникации : дисс. ... докт. филол. наук / Иркутский государственный университет. Иркутск, 2009.

6. Чхетиани Т.Д. Лингвистические аспекты фатической метакоммуникации (на материале английского языка) : дисс. ... канд. филол. наук / Киевский государственный педагогический институт иностранных языков. Киев, 1987. 
7. Watzlawick P., Beavin J.H., Jackson D.D. Pragmatics of human communication. New York : Norton, 1967.

8. Ізотова Н.П. Ігрова стилістика сучасного англомовного художнього наративу в лінгвістичному висвітленні (на матеріалі романів Дж.М. Кутзее) : дис. ... докт. філол. наук / Київський національний лінгвістичний університет. Київ, 2019.

9. Гнезділова Я.В. Когнітивно-дискурсивні моделі англомовної маніпулятивної метакомунікації : дис. ... докт. філол. наук / Київський національний лінгвістичний університет. Київ, 2021.

10. Hübler A., Bublitz W. Introducing metapragmatics inuse.BublitzW.,HüblerA.(Eds.).Metapragmatics in use. Amsterdam, Philadelphia: John Benjamins Publishing Company, 2007. P. 1-28.

\section{REFERENCES}

1. Shevchenko, I. S. (2015). The correlation of informative and phatic functions as the problem of ecolinguistics [Sootnoshenie informativnoy i faticheskoy funktsiy kak problema ekolingvistiki]. Kognitsiya, kommunikatsiya, diskurs, 10, 114-132.

2. Дементьев, В. В. (2010). The theory of speech genres [Teoriya rechevikh zhanrov]. Moscow: Znak.

3. Pocheptsov, G. G. (2009). Selected writings in linguistics [Izbrannie trudi po lingvistike]. Kharkov: V.N. Karazin Kharkov National University.

4. Brown, P., \& Levinson S. C. (1987). Politeness: Some universals in language usage. Cambridge : Cambridge University Press.
5. Gurevich, L. S. (2009). Linua-cognitive space theory of metacommunication [Lingvokognitivnaya teoriya prostrnstva metakommunikatsii] (Thesis for Doctor of Sciences Degree). Irkutsk State University, Irkutsk.

6. Chkhetiani, T. D. (1987). Linguistic aspects of phatic metacommunication (on the material of the English language). [Lingvisticheskie aspektyi faticheskoy metakommunikatsii (na materiale angliyskogo yazyika)] (Thesis for the Candidate Degree in Philology). Kiev State Pedagogical University of Foreign Languages, Kiev.

7. Watzlawick, P., Beavin, J. H., \& Jackson, D. D. (1967). Pragmatics of human communication. New York: Norton.Wierzbicka.

8. Izotova, N. P. (2019). Ludic stylistics of contemporary English fictional narrative from a linguistic perspective: a study of J.M. Coetzee's novels [Igrova stylistyka suchsnogo anglomovnogo khudozhnoho naratyvu $v$ lingvistychnomu vysvitlenni (na materiali romaniv J.M. Coetzee)] (Thesis for Doctor of Sciences Degree). Kyiv National Linguistic University, Kyiv.

9. Gnezdilova Ya. V. (2021). Cognitive and Discourse Models of English Manipulative Metacommunication [Kognityvno-dyskursyvni modeli anglomovnoii manipuliatyvnoii metakomunikatsiii] (Thesis for Doctor of Sciences Degree). Kyiv National Linguistic University, Kyiv.

10. Hübler, A., \& Bublitz, W. (2007). Introducing metapragmatics in use. In W. Bublitz \& A. Hübler (Eds.), Metapragmatics in use (pp. 1-28). Amsterdam, Philadelphia: John Benjamins Publishing Company. 